Portland State University

PDXScholar

6-19-1997

\title{
Evaluating Modernization and Dependency Explanations of the Unequal Distribution of Income in Developing Countries
}

Paul Timothy Shattuck

Portland State University

Follow this and additional works at: https://pdxscholar.library.pdx.edu/open_access_etds

Part of the Growth and Development Commons, Income Distribution Commons, Inequality and Stratification Commons, and the Work, Economy and Organizations Commons Let us know how access to this document benefits you.

\section{Recommended Citation}

Shattuck, Paul Timothy, "Evaluating Modernization and Dependency Explanations of the Unequal Distribution of Income in Developing Countries" (1997). Dissertations and Theses. Paper 5389. https://doi.org/10.15760/etd.7264

This Thesis is brought to you for free and open access. It has been accepted for inclusion in Dissertations and Theses by an authorized administrator of PDXScholar. Please contact us if we can make this document more accessible: pdxscholar@pdx.edu. 


\section{THESIS APPROVAL}

The abstract and thesis of Paul Timothy Shattuck for the Master of Science in

Sociology were presented April 29, 1997, and accepted by the thesis committee and the department.

COMMITTEE APPROVALS:
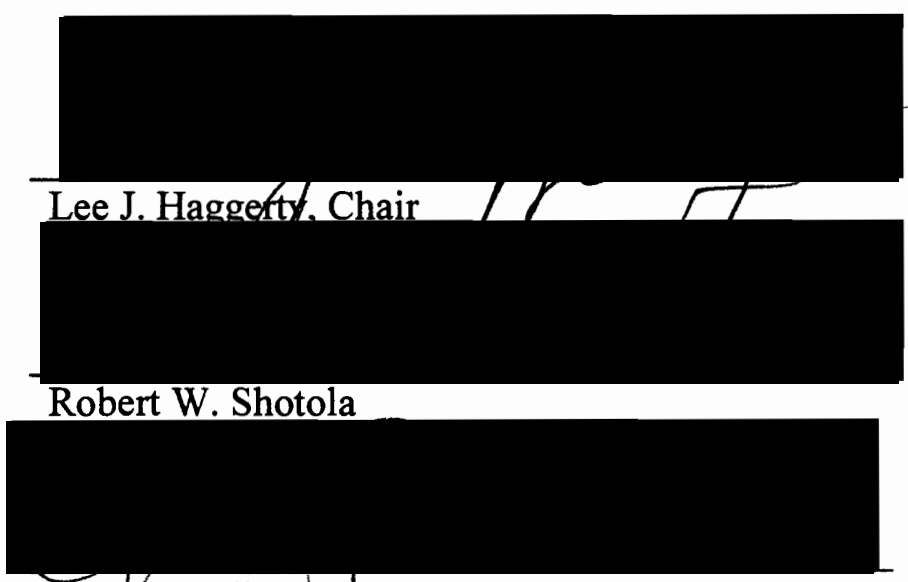

$$
\text { José A. Padin }
$$

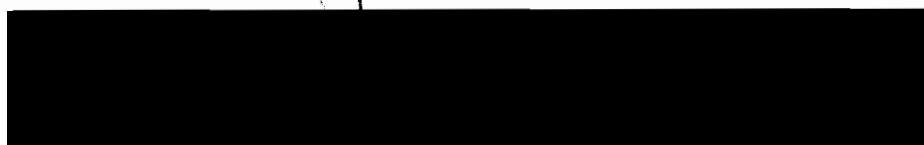

Gerard Mildner

Representative of the Office of Graduate Studies

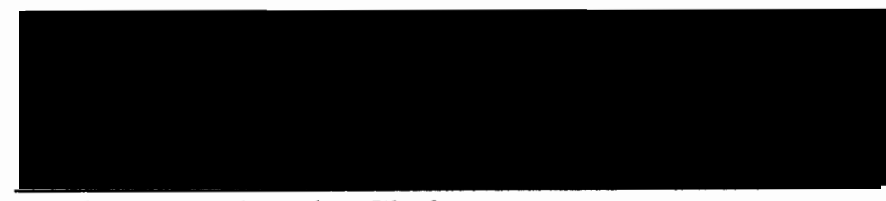

Robert W. Shotola, Chair

Department of Sociology

\section{ACCEPTED FOR PORTLAND STATE UNIVERSITY BY THE LIBRARY}

by

on

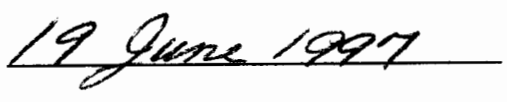




\begin{abstract}
An abstract of the thesis of Paul Timothy Shattuck for the Master of Science in Sociology presented April 29, 1997.
\end{abstract}

Title: Evaluating Modernization And Dependency Explanations Of The Unequal Distribution Of Income In Developing Countries

This paper tests two different theoretical explanations of the causes of the unequal distribution of income in less developed countries using data from circa 1990. There are several reasons for examining this much-studied topic. First, as described in the previous research findings chapter below, there is no consensus in the literature regarding the relative effects of modernization and dependency variables on income inequality. Determining the independent effects of the two models is still an open ended question. Second, the availability of more recent data provides us with an opportunity to check the possibility that previous findings were partly due to the idiosyncratic nature of data that happened to be available circa 1970. Replication is its own justification in this regard. Finally, the rapid increase of economic globalization since 1970 raises the possibility that dependency effects (via more widespread and intensive foreign capital penetration) may actually have increased since previous data was collected.

Multiple regression analysis is used to test several different sets of independent variables derived from the two theoretical perspectives. Results demonstrate strong 
support for the effects of a core modernization model (the percent of labor force working in agriculture, sectoral dualism, secondary education enrollment rate, and population growth) and foreign investment dependence net of one another. Results also suggest the possibility that investment dependence effects have intensified while modernization effects have attenuated since circa 1970. 
EVALUATING MODERNIZATION AND DEPENDENCY EXPLANATIONS OF THE UNEQUAL DISTRIBUTION OF INCOME IN DEVELOPING COUNTRIES

by

PAUL TIMOTHY SHATTUCK

A thesis submitted in partial fulfillment of the requirements for the degree of

MASTER OF SCIENCE

in SOCIOLOGY

Portland State University

1997 


\section{TABLE OF CONTENTS}

INTRODUCTION

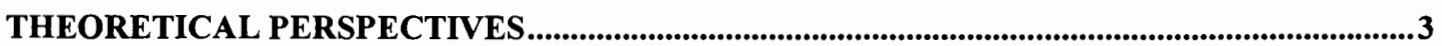

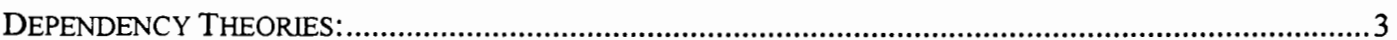

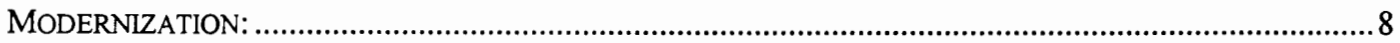

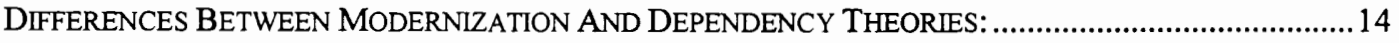

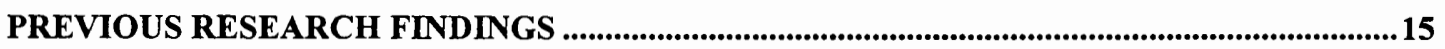

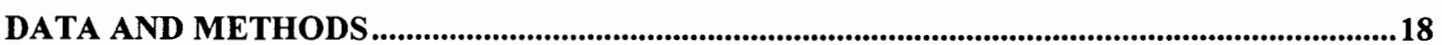

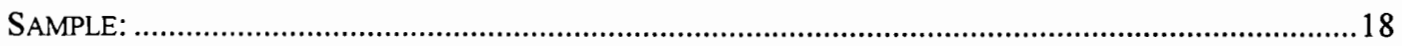

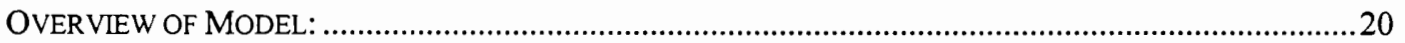

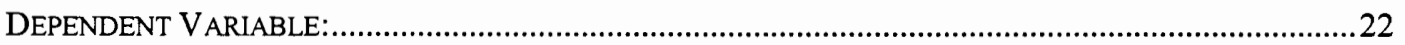

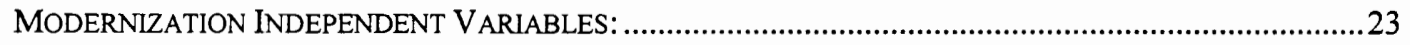

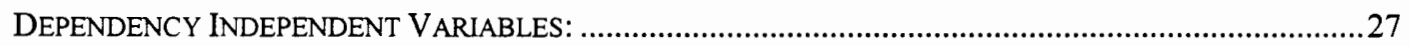

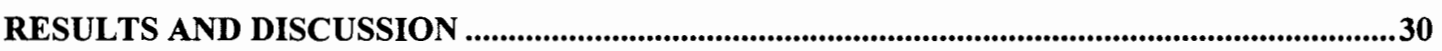

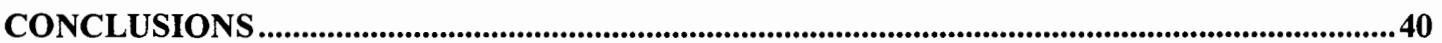

APPENDIX A: EXPLANATION OF GINI COEFFICIENT .....................................................44

APPENDIX B: DEPENDENCY VARIABLES' DISTRIBUTIONS .................................................46

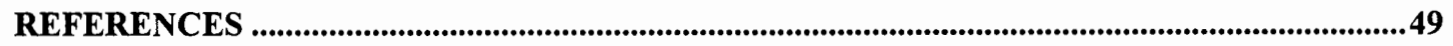

ENDNOTES 


\section{INTRODUCTION}

All nations produce and import economic resources that are used to sustain and enrich life for members. The unequal distribution of economic goods has long been a staple of social research. The sociological perspective on this economic question entails seeing how the unequal distribution is produced, maintained, or reduced by social processes and institutions. A number of previous studies have examined dependency and modernization explanations of income inequality using data from the 1960s and early 1970s (Crenshaw and Ameen 1993, Bornschier and Chase-Dunn 1985, Tsai 1995, Nielsen 1994 \& 1995, Lecaillon et. al. 1984, Dixon and Boswell 1996). I have not found any cross national studies of developing countries that use data more recent than the early 1970s.

There are several reasons for examining this much-studied topic. First, as described in the previous research findings chapter below, there is no consensus in the literature regarding the relative effects of modernization and dependency variables on income inequality. Determining the independent effects of the two models is still an open ended question. Second, the availability of more recent data provides us with an opportunity to check the possibility that previous findings were partly due to the idiosyncratic nature of data that happened to be available circa 1970. Replication is its own justification in this regard. Finally, the rapid increase of economic globalization since 1970 raises the possibility that dependency effects (via more widespread and intensive foreign capital penetration) may actually have increased since previous data was collected. 
This paper tests two different theoretical explanations of the causes of the unequal distribution of income in less developed countries (LDCs) using data from circa 1990. I initially set out to attempt a longitudinal analysis of changes in inequality from 1970 to 1990 as well. However, insurmountable problems with data availability and comparability led me to drop this line of inquiry. 


\section{THEORETICAL PERSPECTIVES}

There are many competing explanations of what causes income inequality in LDCs. Urban bias, the lack of democratic institutions, international exploitation (dependency and world systems theory), and the effects of modernization and economic development are all frequently encountered in the literature. I will compare Kuznets' hypothesis relating economic modernization to inequality with dependency theories relating international exploitation to inequality. Modernization theory is often pitted against dependency theories to see which provides a more powerful explanation of intranational income inequality. I will follow this convention.

Urban bias posits an inter-sectoral and inter-regional income inequality that is outside the scope of this paper's goals. ${ }^{1}$ The relationship between government institutions and inequality is most likely substantial. However, due to the problems associated with specification, operationalization, and data availability (see Sirowy and Inkeles 1991 for a thorough discussion of these challenges and a review of research) I will not include this as an independent variable in my analysis. ${ }^{2}$

\section{Dependency Theories:}

The diverse array of perspectives grouped together under this heading all share the general proposition that the unequal and exploitative nature of the relationships between rich and poor countries produces inequality within poor countries. Thus, a nation's status within the world economy and the resultant organization of production 
bear directly upon its internal distribution of national wealth. Generally speaking, there are differences between world systems theory and dependency theory. However, the specific hypotheses I will examine in this paper do not fall clearly into one camp or the other. Therefore, I use the term 'dependency' rather more loosely than I would if I were writing a paper about different theoretical perspectives on development. Brazilian economist Theotonio Dos Santos formulated a definition of dependency:

By dependence we mean a situation in which the economy of certain countries is conditioned by the development and expansion of another economy to which the former is subjected. The relation of interdependence between two or more economies, and between these and world trade, assumes the form of dependence when some countries (the dominant ones) can expand and can be self-sustaining, while other countries (the dependent ones) can do this only as a reflection of that expansion, which can have either a positive or a negative effect on their immediate development. (1970, p. 193)

Bornschier and Chase-Dunn (1985) develop a set of arguments about the causes of inequality that draw from dependency and world systems theory. These propositions are the most thoroughly developed and tested ones from this perspective. The main assumption from this perspective is that the class structure within a country is in part a reflection of that country's status, location and role in the economicgeographic world hierarchy of nations.

Thus an alliance between core ruling classes (whether mediated by transnational corporations or core states) and peripheral ruling classes (Galtung's "bridgeheads") will tend to produce greater inequalities within peripheral countries because the peripheral elite will be able to use the resource of core support to garner income and other advantages to itself. It will also be more able to successfully resist demands for redistribution. This argument 
implies that it is not a low level of development that creates high inequality, but rather peripherality in the world division of labor and its associated class structure. (p. 23)

The key to their arguments is that participation in the world system gives local political and economic elites a vested interest in pursuing policies and activities that stabilize and further their privileged status and thence reinforce or increase inequality.

The segment of the peripheral economy that is integrated into the worldeconomy is privileged vis-à-vis the marginalized majority. This institutionalized privilege acts as a measure to stabilize the world-hierarchy by the principle of "divide et impera." It is not necessary to assume that specific actors consciously act like this. The frame of reference for the integrated part of the population is the world society. Therefore, the striving for participation in the bourgeois lifestyle of this reference system is likely to produce privileges relative to the average life situation in peripheral countries. The integrated population tries to increase its consumption in order to keep up with core standards. A larger income gap and more intense marginalization in poorer countries than in richer ones is thus likely to be the consequence. (p. 120)

More specifically, Bornschier and Chase-Dunn argue that transnational 'corporate penetration' in LDCs creates and bolsters a local elite class that is then motivated by self interest to pursue policies and activities that foster income inequality. Foreign investment penetration in developed countries is not associated with inequality in their model. Their argument distinguishes among three types of corporate investment in poorer countries: extractive and agricultural industries, manufacturing for the world market, and manufacturing for the domestic market.

According to Bornschier and Chase-Dunn modern agricultural and extractive industries tend to be very capital intensive ventures that pay employees a high wage relative to the average for that country. Although accounting for a small percentage of 
the total work force, these high wage earners will tend to oppose wealth redistribution policies. Thus, foreign corporate investment in extractives (Bornschier and ChaseDunn begin their argument by grouping agriculture and extractives but then end by talking only about extractive industries with no explanation of why agriculture was dropped) should lead to rising levels of inequality as wage earners in the sector mobilize against redistributive policies. McMichael (1996) fills in the argument connecting investment in agriculture and income inequality. Investment and aid aimed at modernizing/westernizing the agricultural sector disproportionately benefits wealthy families who can afford the new technology and seeds. As the productivity of rich families' land increases as a result of adopting new techniques, their income starts to grow more distant from poorer families' income. Also, rising land values result in higher rents for tenant farmers thereby reducing their income. The combined effect of rising incomes among wealthy families and stagnant or declining incomes among poorer families is growing income inequality .

Bornschier and Chase-Dunn go on to argue that political regimes in LDCs can have two different motivations for fostering income inequality depending on whether they are trying to attract firms that manufacture for the world or the domestic market. Firms that manufacture for the world market tend to seek out labor that is cheap relative to its productivity. Thus, political regimes that materially benefit from the presence of such firms will seek to attract and retain them by pursuing policies that keep wages low (for instance prohibiting unions and strikes). Firms that manufacture 
for the domestic market are only interested in the wealthy minority who can afford the products. In the long run it might be to corporations' advantage to foster growing equality and wealth for all so that the market demand would expand. However, in the short term logic of corporate decision making, according to Bornschier and ChaseDunn, firms are only interested in those who can buy their products now. Thus, a domestic market with a small but wealthy elite who can afford the products is arguably more attractive to manufacturers than one with an egalitarian distribution of limited wealth among a larger populace who would not be able to buy any product. Therefore, political regimes will again act to maintain inequality in order to attract and retain firms. Maintenance of low wages in manufacturing combined with growing wages among the local government and managerial elites creates growing inequality.

There are also other, less renowned, theories of the connection between foreign investment and inequality. Crenshaw and Ameen (1993) argue that foreign direct investment $(\mathrm{FDI})^{3}$ in agriculture leads to land enclosure, labor shedding and unemployment. In turn, these lead to landlessness, poverty, and labor over-supply (thereby depressing wages). Pan-Long Tsai (1995) argues that foreign direct investment (FDI) creates a minority of privileged elites associated with the FDI sector. These elites then actively oppose any government redistributive policies that may diminish their incomes. Timberlake (1985) argues that the FDI in peripheral and semiperipheral nations leads governments to increase coercive control of labor in order to attract more FDI. 
Dependence is also thought to be created via external debt and foreign aid. Nembhard (1993) argues that foreign aid (which is often in the form of loans) often exacerbates national inequality because it tends to favor large projects, privileged sectors (i.e. large landholders), and entrenched local elites. She goes on to cite numerous case examples where aid bypassed the poor and mainly benefited elites and transnational corporations. Also, the austerity measures imposed on severely indebted countries are argued to exacerbate inequality because one of the International Monetary Fund's strategies to keep LDCs solvent is to promote the cutting of government employee and contract wages. This sends a ripple effect through the economy and depresses incomes especially at the low end of the earnings distribution.

Chan (1989), Bornschier and Chase-Dunn (1985), and Tsai (1995) have all found a significant correlation between foreign direct investment and national income inequality in LDCs. All of these cross sectional studies focus on data from the 1960s and early 1970 s.

\section{Modernization:}

The classic theoretical statement linking modernization and income inequality was put forth by Simon Kuznets (1955). His conclusions were based on mathematical models of sector dualism and an analysis of the historical experience of Germany, the United Kingdom and the United States. He hypothesized an inverted U-curve relationship between industrialization and inequality with inequality first increasing and then decreasing as a country industrializes. 
Kuznets' main argument revolves around the sectoral shift of the labor force a country experiences as it industrializes. He conceptually divides a country's economy into two sectors: agriculture and all others. Once the economy is divided into two labor sectors then the level of national income inequality can be disaggregated into three sources. First, a difference in average income between the two sectors can contribute to national inequality. This inter-sectoral difference is referred to as sector dualism. Second, inequality in the distribution of income within either or both sectors can affect national inequality. Finally, national inequality is dependent on the share of the labor force participating in each sector.

Based on his historical analysis of the United States, Germany, and the United Kingdom Kuznets speculated that average incomes are typically higher in the nonagricultural than agricultural sector. This supposition has been consistently upheld by empirical evidence. For instance, Lecaillon et. al. (1985:55) report sector dualism for twelve developing countries in the early 1970 s. The ratio of non-agricultural to agricultural income ranged from 2.03:1 in Iran (1972) to 8.85:1 in Swaziland (1974).

Thus, even if we assume the distribution of income within each sector is similar, income inequality will increase and then decrease over time if there is a shift of population from the sector with the lower average income to the one with the higher average income. Kuznets illustrates this point with a table which I have simplified and reproduced as Table 1. "The basic assumptions used throughout are that the per capita income of sector B (nonagricultural) is always higher than that of sector A 
[agricultural]; that the proportion of sector $\mathrm{A}$ in the total number declines; and that the inequality of the income distribution within sector A may be as wide as that within sector B but not wider" (Kuznets, 1955 p.12). In Table 1 sector B's average income is twice that of sector A. Two different distributions are modeled for each sector. One distribution is moderately unequal (distribution $\mathrm{E}$ ) and the other is very unequal (distribution $\mathrm{U}$ ). Distribution $\mathrm{E}$ assumes a $5.5 \%$ share of total income accruing to the lowest decile of the population with each successive decile's share increasing by one percent culminating in $14.5 \%$ for the highest decile. Distribution U starts with one percent of total income for the lowest decile increasing by $2 \%$ each decile reaching $19 \%$ for the top tenth income group.

Table 1 illustrates what happens, given the above assumptions, as the population shifts from 80 to 20 percent in sector $\mathrm{A}$. In all three scenarios inequality first increases and then decreases as population shifts. Based on this example and other mathematical models (Nielsen 1994), the theoretical turning point in the inequality trend is reached when the proportion of population in sector A decreases to approximately sixty percent. 
Table 1. Percentage shares of the first and fifth quintiles in income distribution under varying assumptions, from Kuznets $(1955$, p. 13)

\begin{tabular}{|c|c|c|c|c|c|c|c|}
\hline & \multicolumn{7}{|c|}{ Proportion of Sector A to Total Population } \\
\hline & $\overline{0.8}$ & 0.7 & $\overline{0.6}$ & 0.5 & 0.4 & 0.3 & 0.2 \\
\hline $\begin{array}{l}\text { Per capita income of total } \\
\text { population (assuming income } \\
\text { per head in sector } A=50 \text {, in } \\
\text { sector } B=100,2: 1 \text { ratio) }\end{array}$ & 60 & 65 & 70 & 75 & 80 & 85 & 90 \\
\hline $\begin{array}{c}\text { Distribution } \mathrm{E} \text { for both sectors } \\
\text { Share of first quintile }\end{array}$ & 10.5 & 9.9 & 9.6 & 9.3 & 9.4 & 9.8 & 10.2 \\
\hline Share of fifth quintile & 34.2 & 35.8 & 35.7 & 34.7 & 33.2 & 31.9 & 30.4 \\
\hline Range & 23.7 & 25.9 & 26.1 & 25.3 & 23.9 & 22.1 & 20.2 \\
\hline Distribution U for both sectors & & & & & & & \\
\hline Share of first quintile & 3.8 & 3.8 & 3.7 & 3.7 & 3.8 & 3.8 & 3.9 \\
\hline Share of fifth quintile & 40.7 & 41.9 & 42.9 & 42.7 & 41.5 & 40.2 & 38.7 \\
\hline Range & 36.8 & 38.1 & 39.1 & 39.0 & 37.8 & 36.4 & 34.8 \\
\hline $\begin{array}{l}\text { Distribution } \mathrm{E} \text { for sector } \mathrm{A}, \mathrm{U} \\
\text { for sector B }\end{array}$ & & & & & & & \\
\hline Share of first quintile & 9.3 & 8.3 & 7.4 & 6.7 & 6.0 & 5.4 & 4.9 \\
\hline Share of fifth quintile & 37.7 & 41.0 & 42.9 & 42.7 & 41.5 & 40.2 & 38.7 \\
\hline Range & 28.3 & 32.7 & 35.4 & 36.0 & 35.5 & 34.8 & 33.8 \\
\hline
\end{tabular}

Key: $\mathrm{E}=$ moderately equal, $\mathrm{U}=$ very unequal

This analysis begs the question of what causes inequality within sectors and what accounts for the difference in average income between sectors. Kuznets argued that in the early phase of industrialization there is a massive dislocation of people from rural to urban areas. Recent migrants to the cities are considered to be at a wage negotiation disadvantage because of their unfamiliarity with urban and industrial ways of life. Massive dislocation to urban areas combined with rapidly declining death rates and maintenance of high birth rates works to swell the low-wage labor pool (referred 
to as 'swarming' by Kuznets). The glut of low-wage, dislocated laborers and their negotiation disadvantage combine to depress wages at the low end of the income distribution. Furthermore, the rapid rate of creation and explosive growth of new industries leads to a "rapid rate of creation of new fortunes" (Kuznets 1955, p. 18) which increases the wages and the number of wage earners at the top end of the income distribution. The combination of depressed wages at the low end and inflated earnings at the top end of the income distribution leads to an overall increase in income inequality during the early phase of industrialization.

Kuznets went on to argue that as industrialization progresses the growth in income inequality reaches a peak and then begins to decline for a variety of reasons other than the sectoral shift dynamic. The share of aggregate income accruing to society's top earners decreases as a result of progressive taxes and a decreased rate of fortune building due to declining industrial growth rates. Progressive taxes and social safety net laws also lead to a redistribution of wealth that increases wages at the middle and bottom of the income distribution. Labor laws combined with the increased cultural competence and urban savvy of rural migrants' descendants leads to increased bargaining power for lower income groups and hence higher wages. Also, declining rates of rural to urban migration coupled with falling birth rates (as a result of the demographic transition) evens out the match between labor supply and demand thereby reducing the downward pressure on wages resulting from an oversupply of labor. Thus, increasing wages for low-income groups combined with a decrease in top 
earners' share of aggregate income lead to declining income inequality as industrialization progresses.

More recently, the work of Francois Nielsen $(1994,1995)$ has sought to elaborate and refine the initial work of Kuznets. He has developed a core model of four independent variables which he argues captures the linear and curvilinear (transitory) effects of development on inequality. This model includes sector dualism, percent of labor in agriculture, secondary school enrollment rate, and natural rate of population increase. Secondary school enrollment is proposed as a measure of human capital diffusion and accumulation in the general population. As the supply of educated workers increases there is an expected increase in competition for higher wage jobs which will produce a downward effect on wages at the top end of the earnings distribution and thereby contribute to a decline in inequality. He further speculates that some dependency or world system influences on income inequality would most likely be mediated via this core model.

"My (unverified) assumption is that the effects of 'external' world-system variables would be largely channeled through some of the internal variables (such as sector dualism) that are included in the core model. An immediate area for further research would be to subject this assumption to the test and explore the role of world-system variables in inequality processes within countries." (Nielsen 1994 p. 673)

Thus, from this perspective, dependency variables should not add appreciably to the explanatory power of the modernization model. 
Crenshaw and Ameen (1993), Nielsen (1994 \& 1995), Lecaillon et. al. (1984) and Chan (1989) found positive effects that lend support to modernization theory's hypothesized link between economic development and inequality. As with the above cited dependency studies, the data for these studies focused on the 1960 s and 1970 s.

\section{Differences Between Modernization And Dependency Theories:}

It is important to highlight some of the main differences between these two theoretical perspectives. First of all, modernization theory focuses on intranational causes of inequality while dependency focuses on international causes. Secondly, they both share the same short term prediction of growing income inequality associated with initial industrialization. Finally, they diverge in their long range predictions about inequality. Modernization predicts that national economic growth will eventually take care of inequality 'naturally'. Regardless of its source, investment is good because it promotes growth - capital is capital. Inequality is viewed as a transitory phenomenon. Dependency theory predicts long term maintenance and even worsening of inequality as a result of growth stimulated by foreign investment and trade. All capital is not created equal from this perspective. Depending on its point of origin and which sectors are invested in, capital and the growth it stimulates can be detrimental to equality. Foreign dependence and the inequality it allegedly produces are seen to have a more or less monotonic positive relationship. 


\section{PREVIOUS RESEARCH FINDINGS}

In the past ten years there has been a steady trickle of research on determinants of income inequality in developing countries. Bornschier and Chase-Dunn (1985) found the traditional measures of level of development (GNP per capita and GNPc ${ }^{2}$ ) accounted for $25 \%$ of the variance in Gini for a sample of 72 rich and poor countries circa 1968. Their measure of capital penetration (Total Stock of FDI/ Capital Stock*Total Population) explained another $25 \%$ of variance in Gini for the same sample.

Steve Chan (1989) used three different indicators to measure income inequality in sixty three developing countries circa 1970: percent of total income accruing to the top quintile, percent accruing to bottom two quintiles, and the ratio of the two measures. He used a kitchen sink approach to analysis with a total of twenty independent variables. Of interest here are his findings regarding foreign capital penetration (data pulled directly from Bornschier and Chase-Dunn), GNP per capita, and economic growth rate. Bornschier and Chase-Dunn's penetration measure was consistently the most powerful predictor of income inequality accounting for roughly $30 \%$ of the variance in inequality $\left(\mathrm{R}^{2}\right.$ differed slightly depending which inequality measure was used in the equation). Average rate of economic growth was a distant second and virtually no relation appeared between GNPc and income inequality. 
Crenshaw and Ameen (1993) arrived at the opposite conclusion after analyzing data for thirty six developing countries circa 1970. Their results demonstrate strongest support for an association between GNP/capita and its square, population growth rate, and the percent of the labor force in agriculture. In a regression model including these variables and Bornschier \& Chase-Dunn's capital penetration variable the standardized regression coefficient for the penetration measure is 0.04 . No $t$-statistic is given but it is not flagged as being significant at the .05 level and the text of the article dismisses it as insignificant. They conclude "neither total foreign capital penetration nor penetration in extractives or agriculture exert any strong influence on inequality in this analysis.

Pan-Long Tsai (1995) examines circa 1970 data for sixty poor countries and finds support for a modernization model which includes GNP/capita and percent labor in agriculture while finding only qualified support for the effect of foreign investment on income inequality. Tsai uses the book value of the stock of FDI as a proportion of GDP to measure foreign capital dependence. Investment dependence is the most robust predictor of inequality in several models tested with $t$-values ranging from 2.4 to 4.6. However, Tsai argues the effect of FDI on inequality is strongest in East/Southeast Asian countries while being comparatively weak in other regions and that this gives the appearance of a uniform FDI effect across all countries. The $\mathrm{R}^{2}$ about 0.5 for his model including investment and trade dependence, GNPc and its square, percent labor force in agriculture, average economic growth rate, literacy and 
secondary school enrollment rate, and a measure of government intervention in the economy.

Francois Nielsen (1994) examined intra-national determinants of income inequality for a set of fifty six rich and poor countries circa 1970 . After trying several different combinations of independent variables he arrived at a core model of four variables that explain the most variance in Gini with the fewest variables: secondary school enrollment rate, natural rate of population increase, sector dualism, and percent of labor force in agriculture as a percent of GDP. These four variables accounted for nearly eighty percent of the variance in Gini. The $t$-statistics for all four variables were consistently significant at the .01 level across several different models. In a follow-up study Nielsen (1995) found further support for his core model using a pooled regression model with 279 observations from 88 different countries from 1952 to 1988. He found that his core model captured the curvilinear effect and that adding in level of development (measured by energy consumption per capita) and its square did not appreciably increase the $\mathrm{R}^{2}$.

Dixon and Boswell (1996) examined circa 1970 data for thirty nine developing countries (they do not say which ones). Their model included investment dependence, investment rate, logged GNP per capita and its square, and agricultural inequality. The adjusted $\mathrm{R}^{2}$ was .55 . They found roughly equivalent effects produced by capital penetration, GNP/capita and its square (t-ratios of 2.4, 2.0, and -1.8 respectively). 


\section{DATA AND METHODS}

\section{Sample:}

There is no precise empirical definition of what constitutes a 'less developed country.' Selecting criteria for including countries in my analysis has been a challenge. My first criterion is geographic. Only non-European countries are examined herein due to the historical relationship of colonialism between most European countries and the rest of the world. After this geographic guideline, I have used two other empirical measures to define two samples of LDCs.

My first cross section sample of 47 LDCs is comprised of non-European countries designated as either low- or lower middle-income by the World Bank (1992) (based on 1990 gross national product per capita rankings) and for which income distribution data (circa 1990) is available. From here on I will refer to this set of countries as either the 'inclusive sample' or 'original sample'. It is not a representative or a probability sample. This is an admittedly crude criterion for inclusion. It is the most inclusive possible definition in order to maximize the sample size. The problem this introduces is the possibility of curvilinear relations between inequality and the modernization independent variables as it is unclear where these countries would fall on Kuznets' inverted U-curve. Nielsen $(1994,1995)$ argues that his core model of sector dualism, percent of labor in agriculture, secondary school enrollment rate, and natural rate of population increase captures both the linear and the curvilinear effects predicted by Kuznets. To test for this I will include GDP/capita and 
squared GDP/capita in one of my regression models and see if they add a significant amount of explanation of the variance in Gini above and beyond what is explained by the modernization model.

Another way to approach controlling for curvilinear effects is to use only countries which lie on the ascending leg of the inverted U-curve. My second cross section of twenty seven countries includes all the countries from the initial set of forty seven which are to the left of the apex of Kuznets' inverted U-curve. I will refer to this set as the 'restricted sample' or the 'U-curve sample.' I plotted the log base 10 of GDP/capita (1990) against the Gini coefficient (circa 1990) for a set of sixty five countries (my original 47 plus 18 rich nations). ${ }^{4}$ The log transform was used at the suggestion of Francois Nielsen (1997) in order to even out the distribution of countries (according to GDP/capita) which is "typically highly skewed with a long tail to the right. Logging income makes the distribution more symmetric, which means that cases in the scatterplot of Gini (vertical axis) by income per capita (horizontal axis) are better spread out over the graph, allowing more robust estimation of the Kuznets curve" (5/7/97 e-mail from Nielsen to Shattuck). Restricting my sample by this method is expected to produce only linear (rather than curvilinear) relationships between Kuznets' independent variables and inequality. I will still try a squared GDP/capita term in the analyses of this set of countries. The potential benefit of using this more restrictive inclusion criterion is a more pure representation of hypothesized modernization effects alone and in comparison to dependency effects. 


\section{Overview of Model:}

The variables and related hypotheses for my cross section analysis are summarized in Table 2.

None of the theoretical arguments encountered mention anything about lag effects in the relationship between independent variables and inequality. Most analyses use concurrent measures of all variables. I will follow suit except in the case of the 'swarming' and investment dependence variables. Kuznets argued that a rapid rate of population growth would increase the labor surplus and thereby depress wages on the low end of the earnings distribution. It seems logical to suppose that a precipitous rise in the natural rate of population increase would take fifteen or twenty years to translate into a labor surplus. I will discuss this more below. The foreign investment measure is from 1978 and is simply the most up to date information I could find. 


\begin{tabular}{|c|c|c|}
\hline Abbreviation & Description and Source & Related Hypothesis/Prediction \\
\hline GINI & $\begin{array}{l}\text { Circa } 1990 \text { Gini coefficient of } \\
\text { inequality (World Bank } 1995,1996 \text { ) }\end{array}$ & This is the dependent variable \\
\hline AGLABOR & $\begin{array}{l}\text { Percent of total labor force working in } \\
\text { agriculture } 1990 \text { (World Bank 1996) } \\
\text { (expressed in decimal form) }\end{array}$ & $\begin{array}{l}\text { Higher values of AGLABOR } \\
\text { will be negatively associated } \\
\text { with higher values of GINI }\end{array}$ \\
\hline DUALISM & $\begin{array}{l}\text { Absolute value of the percent of the } \\
\text { labor force in agriculture minus the } \\
\text { percent of GDP produced by the } \\
\text { agricultural sector in } 1990 \text { (World } \\
\text { Bank 1996, 1992) (expressed in } \\
\text { decimal form) }\end{array}$ & $\begin{array}{l}\text { Higher values of DUALISM } \\
\text { will be positively associated } \\
\text { with higher values of GINI }\end{array}$ \\
\hline GROWTH & $\begin{array}{l}\text { Average annual growth rate of Gross } \\
\text { Domestic Product, } 1980-1990 \\
\text { (World Bank 1992) (expressed in } \\
\text { decimal form) }\end{array}$ & $\begin{array}{l}\text { Higher values of GROWTH } \\
\text { will be positively associated } \\
\text { with higher values of GINI }\end{array}$ \\
\hline SWARM & $\begin{array}{l}\text { Natural rate of population increase } \\
1970 \text { (World Bank 1994) }\end{array}$ & $\begin{array}{l}\text { Higher values of SWARM } \\
\text { will be positively associated } \\
\text { with higher values of GINI }\end{array}$ \\
\hline EDUCATE & $\begin{array}{l}\text { Percentage of age group enrolled in } \\
\text { secondary education (World Bank } \\
1993 \text { ) }\end{array}$ & $\begin{array}{l}\text { Higher values of EDUCATE } \\
\text { will be negatively associated } \\
\text { with higher values of GINI }\end{array}$ \\
\hline GDPcPPP & $\begin{array}{l}\text { Gross Domestic Product per capita } \\
\text { adjusted for purchasing power parity } \\
1990 \text { (World Bank 1992), millions of } \\
\$\end{array}$ & $\begin{array}{l}\text { Higher values of GDPcPP P } \\
\text { will be positively associated } \\
\text { with higher values of GINI }\end{array}$ \\
\hline $\mathrm{GDPcPPP}^{2}$ & GDPcPPP squared & $\begin{array}{l}\text { Higher values of GDPcPPP } \\
\text { will be negatively associated } \\
\text { with higher values of GINI }\end{array}$ \\
\hline FDI & $\begin{array}{l}\text { Stock of foreign direct investment as } \\
\text { of the end of } 1978 \text { as a proportion of } \\
\text { GDP } 1990 \text { (UNCTC } 1983 \text { and World } \\
\text { Bank 1992). Natural log transform. }\end{array}$ & $\begin{array}{l}\text { Higher values of FDI will be } \\
\text { positively associated with } \\
\text { higher values of GINI }\end{array}$ \\
\hline DEBT & $\begin{array}{l}\text { Total external outstanding debt as a } \\
\text { percentage of GNP } 1990 \text { (World Bank } \\
\text { 1992). Natural log transform. }\end{array}$ & $\begin{array}{l}\text { Higher values of DEBT will } \\
\text { be positively associated with } \\
\text { higher values of GINI }\end{array}$ \\
\hline AID & $\begin{array}{l}\text { Average annual official development } \\
\text { aid (from 1986-1990 in } 1992 \text { constant } \\
\text { dollars) per capita } 1990 \text { (World Bank } \\
\text { 1992). Natural log transform. }\end{array}$ & $\begin{array}{l}\text { Higher values of AID will be } \\
\text { positively associated with } \\
\text { higher values of GINI }\end{array}$ \\
\hline
\end{tabular}




\section{Dependent Variable:}

The 1995 and 1996 World Development Reports list shares of aggregate income by population quintiles for each nation in the sample. I have used this data to calculate Gini coefficients of inequality for each country. However, several data imperfections must be noted. First, the year data was collected for each country varies from 1981 to 1994 (1990 on average). However, Chan (1989) argues that several studies indicate income distribution is quite stable over short periods of time and hence the lack of perfect time matching among countries and between dependent and independent variables should minimally affect the substantive results of analysis.

Another potential problem with the dependent measure is its cross sectional nature. Kuznets (1955) pointed out that nations in the early stages of industrialization may be more vulnerable to "transient disturbances" of the economy such as crop failures and natural calamities because they lack the infrastructure and resources 'cushion' that more developed countries have to mitigate such adverse effects. Thus, income distributions may fluctuate in LDCs quite dramatically from year to year and measures based on only one year (as opposed to multi-year averaging) may be misleading. However, as noted above, several studies have demonstrated that income distributions in LDCs are quite stable over short periods of time (5 to 10 years).

Ahluwalia (1974) argued that even though this kind of cross national data is fraught with problems "they are also the only data we have" (p.34). Therefore, I 
propose that the results of this kind of empirical analysis should be taken as suggestive rather than conclusive.

\section{Modernization Independent Variables:}

1. AGLABOR: Percentage of total labor force working in agriculture 1990. (Labor force is the population between 15 and 64 years of age. Agriculture includes farming, hunting, fishing, forestry, and livestock raising.) The percent of the labor force employed in the agricultural sector is expected to be inversely related to overall inequality. Remember that Kuznets argued economic modernization entails a shift of population and labor from rural agriculture to urban industry. The effect this population shift will have on national income inequality will depend on the magnitude of shift, the inequality of the distribution of income within each sector, and the difference in average wages between the two sectors. An ideal analysis of income inequality would thus include measures of the difference in average income between the two sectors (sectoral dualism), the distribution of income within each sector, and the share of the labor force within each sector. The distribution of income within each sector is unavailable for most countries. However, we can construct measures of sectoral dualism and the share of labor force in each sector. Kuznets assumed that income is generally more equally distributed in the agricultural sector than in the urban sector. "The income 
distribution of the total population, in the simplest model, may therefore be viewed as a combination of the income distribution of the rural and of the urban populations....all other conditions being equal, the increasing weight of urban population means an increasing share for the more unequal of the two component distributions" (Kuznets 1955, pp. 7-8). As data on the distribution of income within each sector is generally unavailable we assume that a shift of labor force from the more equally distributed agricultural sector to the less equally distributed urban sector will increase inequality.

2. DUALISM: Absolute value of the percent of the labor force in agriculture minus the percent of GDP produced by the agricultural sector in 1990 (following Nielsen $\left.1994^{5}\right)$. Dualism is expected to be positively associated with inequality. The difference in average income between the rural and urban sectors is one of the other components of changing national income inequality resulting from a shift of labor.

3. SWARM: The natural rate of population increase in 1970. Swarming is expected to be positively associated with inequality. Kuznets asserted "the 'swarming' of population incident upon a rapid decline in death rates and the maintenance or even rise of birth rates, would be unfavorable to the relative economic position of lower-income groups." (1955 p.18) Rapid population growth is expected to increase the labor surplus thereby driving wages down at the low end of the wage distribution and resulting in increased income inequality. This is the only 
independent variable for which I can make a clear argument for lag effects. If the natural rate of population increase is high then it is reasonable to speculate the resultant birth cohort will not have a potentially depressant effect on wages until they reach working age. Thus, I would argue against Nielsen's (1994) approach of using the natural rate of population increase concurrent with the measure of inequality as an indicator of swarming. I think it is logical to use a twenty year lag. A high rate of natural increase is hypothesized to increase inequality twenty years later as that birth cohort enters the labor force.

4. GROWTH: The average annual growth of gross domestic product from 1980 to 1990. Growth is expected to be positively associated with inequality. Kuznets argued that rapid economic growth leads to fortune building which increases the share of wealth at the top end of the earnings distribution and hence increases inequality.

5. EDUCATE: Percentage of age group enrolled in secondary education as of 1990. This is a measure of the spread of human capital and is expected to have a negative relation with inequality following Nielsen's arguments (1994 \& 1995) described above.

6. GDPcPPP: Gross domestic product per capita 1990 adjusted for purchasing power parity. This measures overall level of economic development. GDP per capita is expected to be positively associated with inequality. "One might thus assume a long swing in the inequality characterizing the secular income structure: widening 
in the early phases of economic growth when the transition from the pre-industrial to the industrial civilization was most $\underline{\text { rapid; }}$; becoming stabilized for a while; and then narrowing in the later phases. This long secular swing would be most pronounced for older countries where the dislocation effects of the earlier phases of modern economic growth were most conspicuous; but it might be found also in the 'younger' countries like the United States..." (Kuznets, 1955 p 18, emphasis added). This is the classic statement of the famed 'inverted U-curve hypothesis.' This is frequently interpreted by researchers as implying a curvilinear relationship between 'level of development' and inequality. However, in the context of his overall argument and taking note of the highlighted words it has become clear to me that Kuznets was primarily making an argument about the relationship between the dislocating and sectoral shift effects of industrialization and urbanization frequently accompanying 'development.' Thus, 'level of development' is really referring to the concepts of dualism and relative integration into the modern market sector. However, most researchers utilize gross domestic or national product per capita as a catch-all measure of level of development and ignore the more detailed process Kuznets described. Nielsen (1995) and Lecaillon et. al. (1984) are the only researchers I have found who specifically note this important distinction. It is clear that in many developing countries with export processing zones located away from existing urban centers that there is little or no connection between urbanization and industrialization or growth in productivity. Similarly, 
growth in productivity may increase with little sectoral labor shift in countries whose wealth creation comes from extractive industries such as mining or oil. The best rationale I have found for including a measure of national productivity comes from Pan-Long Tsai (1995). He suggests that some growth in economic surplus is generally a prerequisite to a growth in inequality of the distribution of wealth. Of course this ignores the role of brute force and social organizations such as caste and slavery in creating economic inequality. However, all other things being equal, it stands to reason that countries with virtually no productive wealth have less 'latent potential' for unequal distribution than countries with some form of surplus wealth. Thus, the hypothesized link between relative level of national productivity and inequality remains rather fuzzy. Therefore, I will follow Nielsen by including productivity in a separate model after first examining the previous indicators of aglabor, dualism, swarming, education, and growth rate.

7. GDPcPPP ${ }^{2}$ : This squared term is intended to capture inverted u-curve effects not explained by the theoretically derived variables.

\section{Dependency Independent Variables:}

The distributions of all three dependency variables are highly skewed with long tails to the right. In order to use them in regression analyses I performed a natural log transformation for each which dramatically evens out their distributions. (See Appendix B for original and transformed distributions). 
1. FDI: Stock of foreign direct investment as of the end of 1978 as a proportion of Gross Domestic Product (1990). Investment dependence is expected to be positively associated with inequality. According to Bornschier and Chase-Dunn (1985) an ideal measure of investment dependence is the total accumulated stock invested in an LDC by transnational corporations weighted by a nation's overall total capital stock and the size of the labor force (capital and labor being two major factors of production). The measure they actually use substitutes total population as a proxy for labor force. Unfortunately, I have been unable to find data on nations' total capital stock. My measure follows that used by Dixon and Boswell (1996) and is as good as available data allows.

2. DEBT: Total external outstanding debt as a percentage of GNP (1990). Debt dependence is expected to be positively related to inequality based on the arguments presented above. The only recent study I have found that uses a debt dependence measure (debt service as a proportion of GNP) is Chan (1989). However, annual debt service fluctuates dramatically along with changes in interest rates which renders this an unreliable measure in my opinion. I have chosen to use the net present value of total external debt as a percentage of GNP in 1990. This is a widely available measure that is frequently used by banks in loan eligibility analyses. It gives an indication of how much outstanding debt a country has relative to its overall level of economic productivity. 
3. AID: The five year average (in 1992 dollars) of annual net disbursements (includes "gross disbursements less payments to the originators of aid for amortization of past aid receipts”, World Bank 1995, p. 238) of official development assistance (includes loans, grants and technical assistance) from all sources 1986 to 1990 per capita (population in 1990). Based on the dependency argument of Nembhard (1993) aid dependence is expected to be positively associated with inequality. 


\section{RESULTS AND DISCUSSION}

Table 3 presents the inclusive sample of forty seven countries ranked by circa 1990 Gini coefficients and includes the year income distribution data was actually collected.

TABLE 3. Inclusive Sample Ranked by Gini c. 1990

\begin{tabular}{|l|c|c|l|c|c|}
\hline COUNTRY & $\begin{array}{c}\text { ACTUAL } \\
\text { YEAR }\end{array}$ & $\begin{array}{c}\text { GINI c. } \\
\mathbf{1 9 9 0}\end{array}$ & COUNTRY & $\begin{array}{c}\text { ACTUAL } \\
\text { YEAR }\end{array}$ & $\begin{array}{c}\text { GINI c. } \\
\mathbf{1 9 9 0}\end{array}$ \\
\hline Brazil & 1989 & 0.569 & Nigeria* & 1992 & 0.395 \\
\hline Guatemala* & 1989 & 0.538 & Mauritania* & $1987-88$ & 0.393 \\
\hline Tanzania* & 1991 & 0.535 & Bolivia* & $1990-91$ & 0.390 \\
\hline Honduras* & 1989 & 0.533 & Jamaica & 1990 & 0.384 \\
\hline South Africa & 1993 & 0.528 & Philippines* & 1988 & 0.375 \\
\hline Panama & 1989 & 0.518 & Jordan & 1991 & 0.372 \\
\hline Zimbabwe* & $1990-91$ & 0.511 & Tunisia & 1990 & 0.370 \\
\hline Kenya* & 1992 & 0.510 & Morocco* & $1990-91$ & 0.362 \\
\hline Lesotho* & $1986-87$ & 0.508 & Algeria & 1988 & 0.356 \\
\hline Chile & 1992 & 0.502 & Cote d'Ivoire* & 1988 & 0.342 \\
\hline Botswana & $1985-86$ & 0.492 & Ghana* & $1988-89$ & 0.339 \\
\hline Senegal* & $1991-92$ & 0.490 & China* & 1990 & 0.337 \\
\hline Venezuela & 1990 & 0.486 & Vietnam & 1992 & 0.330 \\
\hline Colombia & 1991 & 0.469 & Korea, Rep. & 1988 & 0.316 \\
\hline Mexico & 1992 & 0.460 & Uganda* & $1989-90$ & 0.305 \\
\hline $\begin{array}{l}\text { Dominican } \\
\text { Rep.* }\end{array}$ & 1989 & 0.459 & Indonesia* & 1990 & 0.304 \\
\hline Nicaragua & 1993 & 0.456 & Egypt & 1991 & 0.295 \\
\hline Malaysia & 1989 & 0.441 & Ethiopia* & $1981-82$ & 0.294 \\
\hline Costa Rica & 1989 & 0.425 & India* & 1989 & 0.294 \\
\hline Ecuador & 1994 & 0.422 & Pakistan* & 1991 & 0.287 \\
\hline Peru* & 1994 & 0.413 & Nepal* & $1984-85$ & 0.279 \\
\hline Thailand & 1988 & 0.400 & Sri Lanka* & 1990 & 0.278 \\
\hline Zambia* & 1991 & 0.398 & Rwanda* & $1983-84$ & 0.268 \\
\hline & & & Bangladesh* & $1988-89$ & 0.265 \\
\hline N*47, Average & & & & & \\
\hline
\end{tabular}

$\mathrm{N}=47$, Average Gini $=0.404$, Average year of measurement $=1990,{ }^{*}=$ countries included in restricted sample 
Table 4 presents descriptive information about all of the variables in the inclusive sample. Table 5 is the correlation matrix for all variables.

TABLE 4. Summary of Cross Section Variables

\begin{tabular}{|lrrrrrr|}
\hline & Minimum & Maximum & \multicolumn{1}{l}{ Range } & Mean & \multicolumn{1}{l}{$\begin{array}{l}\text { Stnd. } \\
\text { Dev. }\end{array}$} & N \\
\hline GINI & 0.265 & 0.569 & 0.304 & 0.404 & 0.089 & 47 \\
\hline AGLABOR & 0.12 & 0.94 & 0.82 & 0.48 & 0.23 & 47 \\
\hline DUALISM & 0.06 & 0.58 & 0.52 & 0.26 & 0.16 & 43 \\
\hline SWARM & 19 & 37 & 18 & 28 & 4.5 & 45 \\
\hline EDUCATE & 4 & 87 & 83 & 39.81 & 20.96 & 43 \\
\hline GROWTH & -0.02 & 0.11 & 0.14 & 0.03 & 0.03 & 45 \\
\hline GDPcPPP & 310 & 7190 & 6880 & 2931 & 1867 & 45 \\
\hline GDPcPPP & 96,100 & 51696100 & $51,600,000$ & $12,000,057$ & $13,357,477$ & 45 \\
\hline lnFDI & -5.67 & -.41 & 5.25 & -3.52 & 1.13 & 43 \\
\hline lnDEBT & 2.67 & 5.64 & 2.97 & 4.21 & 0.71 & 44 \\
\hline lnAID & -.69 & 5.14 & 5.83 & 2.78 & 1.41 & 46 \\
\hline
\end{tabular}

GINI, the modernization and the log transformed dependency independent variables are all pretty evenly distributed around their means. Prior to running the regression analyses I examined box plots of all independent variables and scatter plots of all independent variables against the dependent variable to check for non-linearity, outliers, and possible threshold or ceiling effects. I could detect none of these problems visually with any of the variables. The regression results are presented in Tables 6 and 7. All models were computed using the ordinary least squares method. 


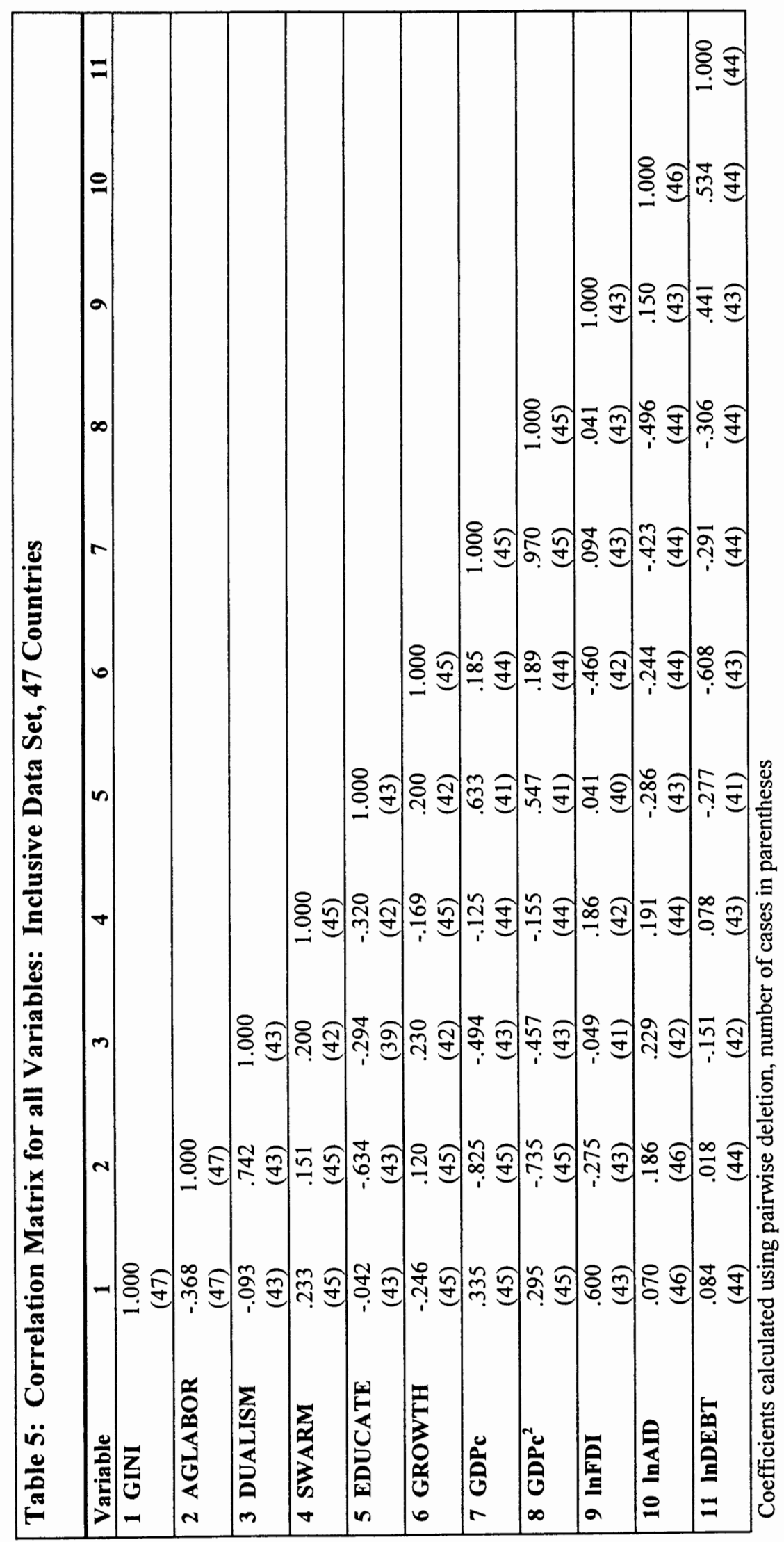




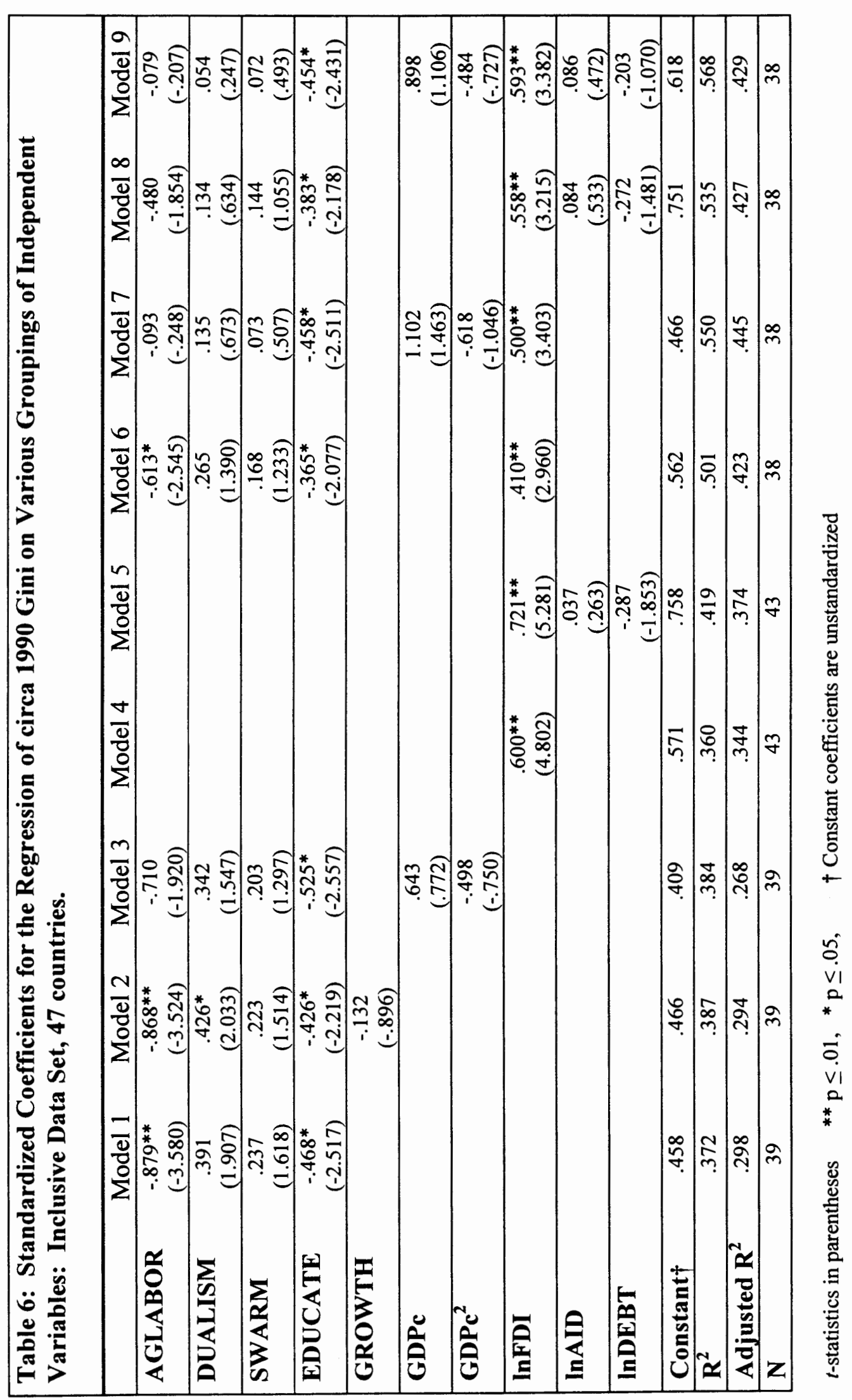


Table 6 presents the regression results for the inclusive data set of all 47 countries. Model 1 is the same as Nielsen's (1994 \& 1995) core model. In analyses of 56 countries circa 1970 Nielsen (1994) consistently came up with coefficients with $t$ statistics significant at the .05 level and an $\mathrm{R}^{2}$ around .800 . My sample produces an adjusted $\mathrm{R}^{2}$ of .298 from Nielsen's core model variables of percent labor in agriculture, dualism, population swarming, and spread of education. The difference in our results may be largely due to the fact he included rich countries in his analysis which would possibly accentuate coefficients of a model which is designed to capture curvilinear relationships found in a sample with both rich and poor countries. Since my sample includes only low and middle income countries, the curvilinear effects described by his core model may be attenuated in this analysis.

Model 2 adds in the growth variable derived from Kuznets. High growth rates were expected to lead to rapid rates of fortune building among the wealthy members of society and thence to increase inequality. However, the negative correlation coefficient between GROWTH and GINI from Table 5 combined with the negative regression coefficient of model 2 in Table 6 would seem to refute this hypothesis. Also, the addition of the growth variable adds virtually nothing to the explanatory power of Nielsen's core model.

Model 3 adds in level of development measures to Model 1. As predicted, these variables add virtually nothing to the explanatory power of Nielsen's core model. This bolsters his assertion that the four variables in Model 1 of Table 6 capture the 
relation between development and inequality better than a summary measure of development. While not presented in the results table, I did a regression model with just GDP and GDP ${ }^{2}$. The $\mathrm{R}^{2}$ was only .086 with neither coefficient's $t$-statistic even close to significance at the .05 level.

Model 4 shows the coefficient for the investment dependence measure. I separated this out from the other dependence measures because investment dependence is much more thoroughly theorized and specified in the literature than the other two dependence measures. I wanted to be able to compare my findings with previous research. The high $\mathrm{R}^{2}$ and robust $t$-statistic indicate that investment dependence alone is a very strong predictor of income inequality for this sample of countries.

Model 5 adds the other two dependence measures to create a complete dependency model. The aid measure is consistently insignificant across all models. This may be an artifact of it being a flow measure rather than a penetration measure. Perhaps in the future it would be worth trying to construct a measure of cumulative foreign aid weighted by the size of the economy. Interestingly the debt measure consistently has a negative coefficient and falls just short of significance at the .05 level. This is opposite the expected positive relation between debt and inequality. The very low correlation between debt and inequality $(0.084)$ indicates that debt's inverse relation with Gini only occurs when investment dependence is held constant. 
Model 6 presents Nielsen's core model plus the investment dependence measure. The robust significance of investment dependence across models and the difference of roughly 0.1 in $R^{2}$ between model 1 and model 6 indicate Nielsen was incorrect in assuming dependency would effect inequality mainly via the variables in his core model. Investment dependence clearly has a substantial effect on inequality independent of Nielsen's core model variables.

Models 7, 8, and 9 merely try different combinations of variables to see which ones are most robust. The education and investment dependence measures are the most robust predictors of inequality across all the different models. AGLABOR is extremely attenuated in combination with the GDP and investment dependence measures indicating possible collinearity problems.

Table 7 presents the regression results of four models using only the 27 countries on the ascending leg of the Kuznets inverted U-curve. This is intended as another way of controlling for curvilinear effects. The drop in $\mathrm{R}^{2}$ for Nielsen's core model (model 1 in both tables) from Table 6 to Table 7 further suggests that his model is strongest as a predictor of curvilinear effects found in a larger sample including both rich and poor countries. The increased robustness of the investment dependence measure indicates the possibility that dependency is a stronger predictor of inequality for very poor countries than for a mix of poor and middle income countries. This further supports the work of Bornschier and Chase-Dunn (1985) who assert that investment penetration has the greatest impact on inequality in very poor countries and 
comes to have an inverse relation with inequality in rich countries. Thus, if we were to model the effect of investment penetration for a large sample of rich and poor countries it would be advisable to use a quadratic function for the investment measure or use a dummy variable for rich/poor to tease out this opposite effect. 


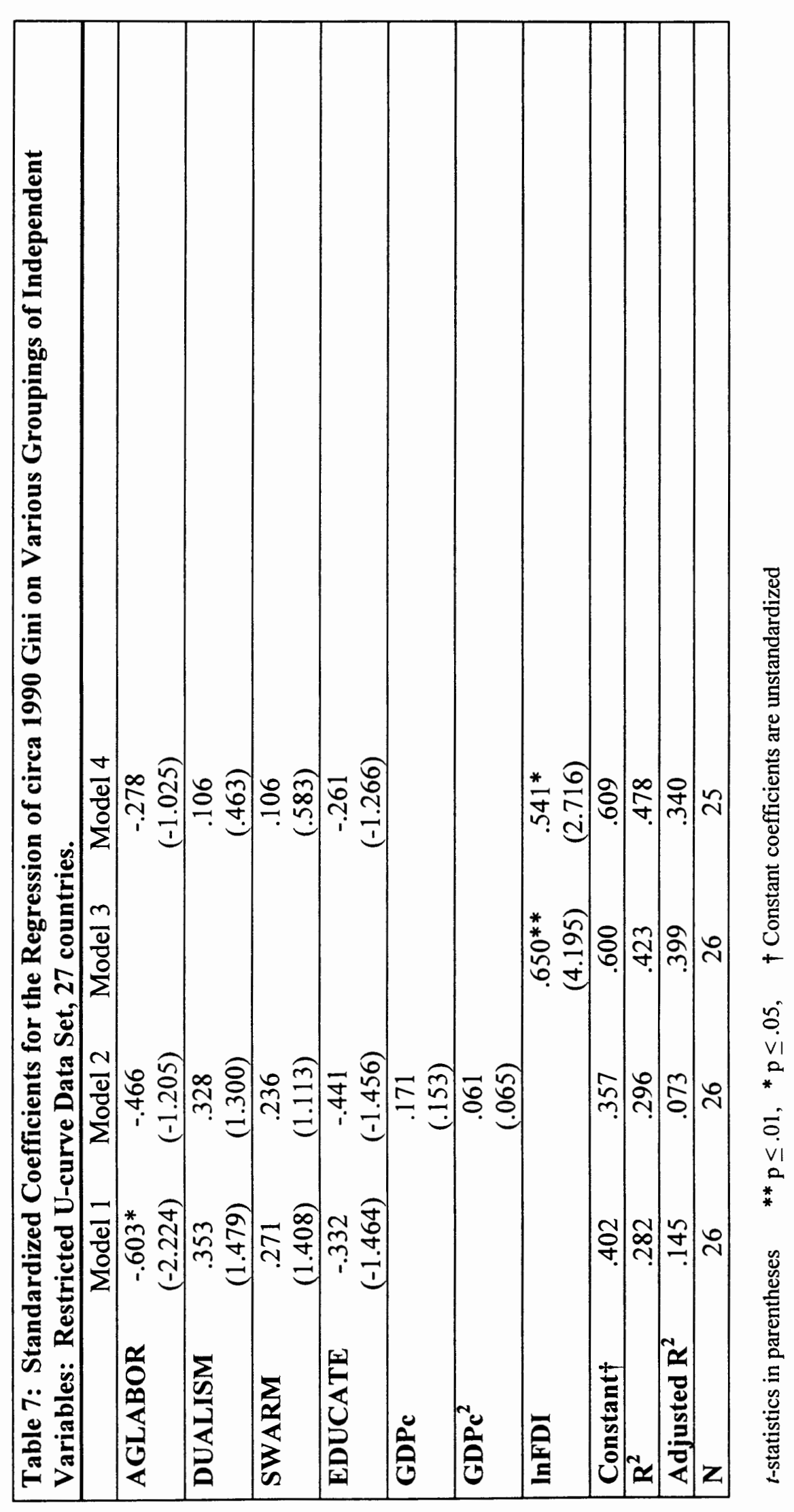


Dixon and Boswell (1996), Crenshaw and Ameen (1993), Chan (1989), PanLong Tsai (1995), and Bornschier and Chase-Dunn (1985) all use logged GNP and $\mathrm{GNP}^{2}$ measures in their analyses of inequality in LDCs. I wonder to what extent this affected their results. Using a $\log$ transform can be justified when examining both rich and poor countries because, as noted above, this tends to yield a highly skewed distribution with a long tail to the right. However, in analyses that examine only poor countries I challenge this practice and suspect it may introduce false effects. GDP per capita was quite evenly distributed for my sample of countries. Also, I could discern no curvilinear relation between GDPc and GINI either in a scatterplot or by comparing linear to quadratic equation results in bivariate regressions. In order to compare my results to others I tried using the natural $\log$ of GDP and its square. I found that this did nothing to improve the distribution of these variables and that using the logged terms in regression equations did not change the substantive results. 


\section{CONCLUSIONS}

I set out to test hypotheses about the causes of income inequality in developing countries derived from two different theoretical perspectives. I found support for some hypotheses from each theory.

Because different researchers use different models it is impossible to make pure comparisons with my results. However, my model seems to demonstrate a stronger relationship between investment dependence and inequality compared to the findings of Bornschier and Chase-Dunn (1985), Chan (1989), Crenshaw and Ameen (1993), Pan-Long Tsai (1995), and Dixon and Boswell (1996). The investment dependence measure in my model accounted for roughly $35 \%$ of the variance in inequality for my sample of 47 countries. This is higher than Bornschier and ChaseDunn's (1985) $25 \%$ and Chan's (1989) 30\% figures. This lends support to the notion that dependency effects have increased apace intensified economic integration since the 1970s.

Furthermore, it is clear that investment dependence exerts an effect on inequality independent of Nielsen's core modernization model. Thus, foreign investment may influence inequality partially, but certainly not entirely, through the variables of dualism, percent labor in agriculture, secondary education enrollment rate, and population growth. I think the bottom line is that we need to examine both intra- 
and inter-national factors in order to develop a thorough explanation of income inequality.

It is interesting to note that none of my models explained as much total variance in inequality as any of the previous researchers. As noted above, various models from different studies accounted for anywhere between $50 \%$ and $80 \%$ of variance in inequality for different sets of countries circa 1970. This is possibly an artifact of differences in methodology. However, it also seems possible this is due to a diminished explanatory power of traditional modernization variables since the late 1960s. This conclusion is bolstered by the fact that none of my modernization models (Nielsen's core model or the combination of GDPc and its square) explained nearly as much variance in inequality as ones tested on circa 1970 data. Much has changed in the world economy since 1970 . These changes and their effects would be a fruitful direction for future research to consider.

My findings demonstrate no support for the hypothesized effects of economic growth, foreign aid, and foreign debt. The operationalization of the aid dependence measure should be reconsidered in future research in order to take account of the cumulative effect of aid over time. The apparent inverse relation between growth and inequality warrants further investigation. The inverse relation between debt and inequality when investment dependence is held constant also deserves more consideration. 
The reason most social scientists study a topic like inequality is because we are concerned about poverty and injustice. The implicit assumption in most cross national income inequality studies is ceteris paribus, the lower the Gini, the better off people are in that country compared to other countries. However, as a dependent variable, the Gini coefficient does not hold all other things equal. Less developed countries with low income inequality also tend to be the poorest of the poor and have a very high percentage of the population working in agriculture. It is important to remember that the Gini is merely a measure of the distribution of income with no reference to a nation's level of income. Thus, a low Gini in a very poor country simply means that poverty is equally distributed.

This study has made me wonder about the relation between income inequality and other measures such as the Physical Quality of Life Index or the United Nations' Human Development Index. I would also like to try grouping countries into comparable levels of national productivity and see how this affects my results. I am currently developing a measure of income inequality that is weighted by national wealth in order to more accurately compare the economic welfare of the poorest members of different countries. This would be a good direction for future research. Another next step for my continuation of this line of research includes learning about regression diagnostics. One thing I have learned from this project is how the substance of quantitative findings can hinge on relatively subtle methodological 
details. Delving into these analyses has made me a skeptical consumer of quantitative research literature.

Finally, I need to immerse myself more in the historical details and theoretical accounts of globalization and development. I have raised several interesting questions in this project which I simply do not have the knowledge base to answer at this point. I am particularly interested in exploring the possibility of diminished modernization and intensified dependency effects since the 1970 s. 


\section{APPENDIX A: EXPLANATION OF GINI COEFFICIENT}

The Gini coefficient is a commonly used measure of inequality based on the Lorenz curve that is easily calculated given quintile income distribution data. The chart below relates the cumulative percent of aggregate income earned by quintiles to quintiles of the population. The straight diagonal line represents perfect equality wherein each unit (individual, family, household) earns the same income. The other two lines represent the Lorenz curves of Hungary and Brazil circa 1990. The Gini coefficient is simply the ratio of the area between the Lorenz curve and the line of perfect equality to the total area under the line of perfect equality. The formula I used is derived from Ehrenberg and Smith (1994, p. 557).

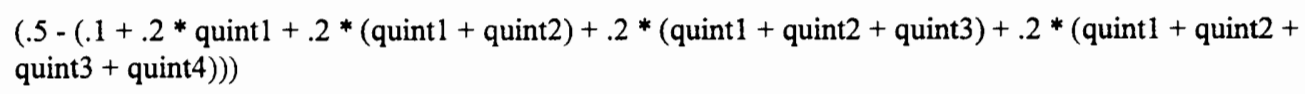

quint 1 through 4 = the quintile's share of aggregate income expressed in decimal form. 
Lorerz A ves of Hungary (gini = .216) and Brapi (gini =.569), 1989

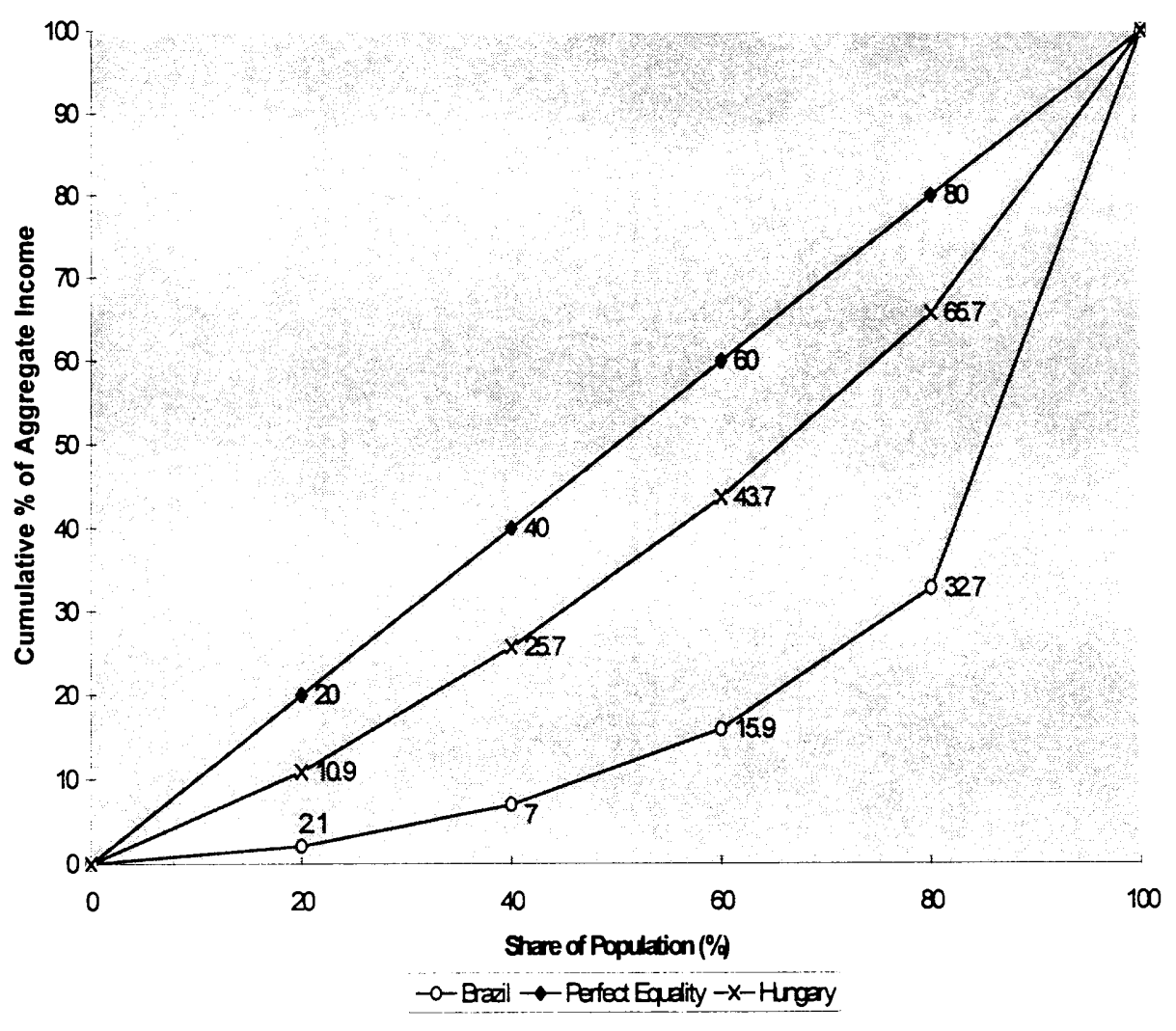




\section{APPENDIX B: DEPENDENCY VARIABLES' DISTRIBUTIONS}

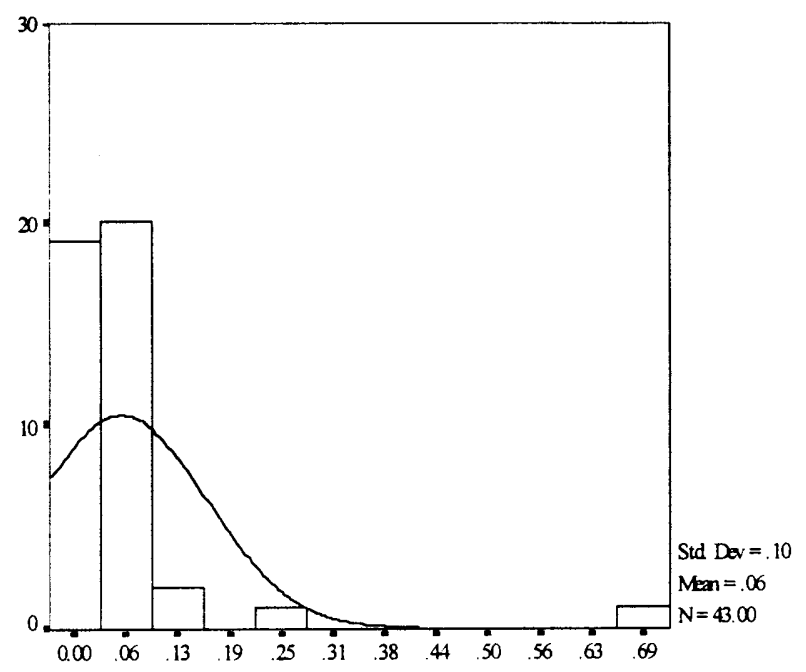

FDI stock 1978 / GDP 1990

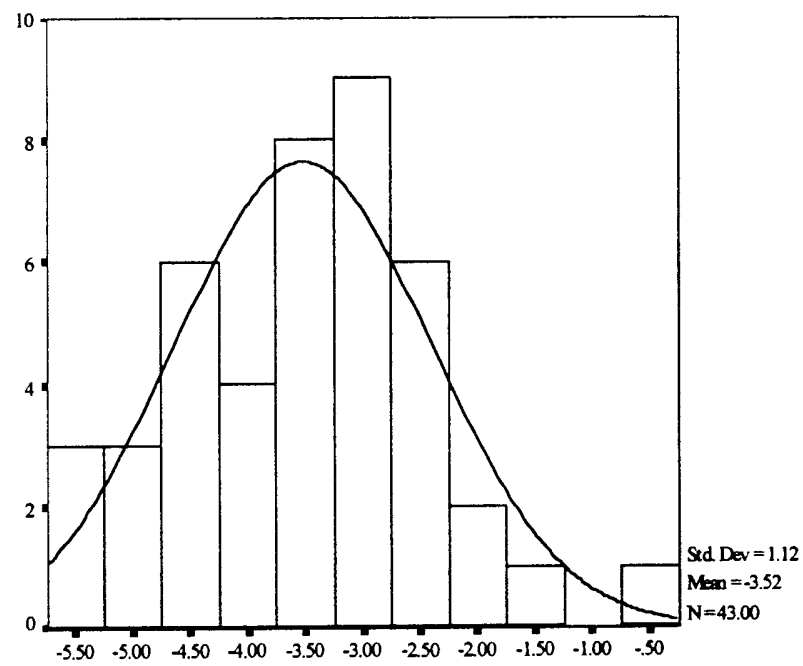

Natural log of FDI measure 


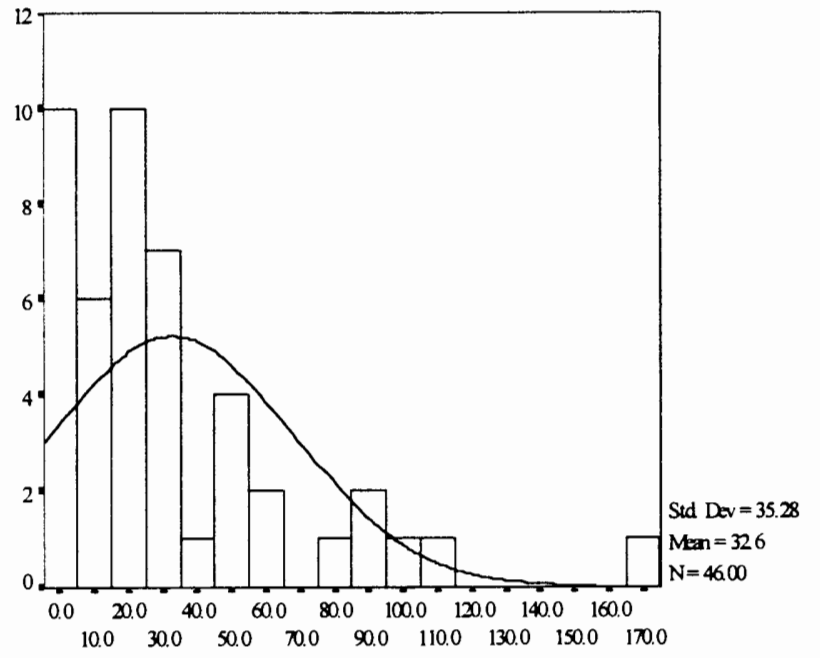

Avg. annual official development aid (1986-90) per capita (1990)

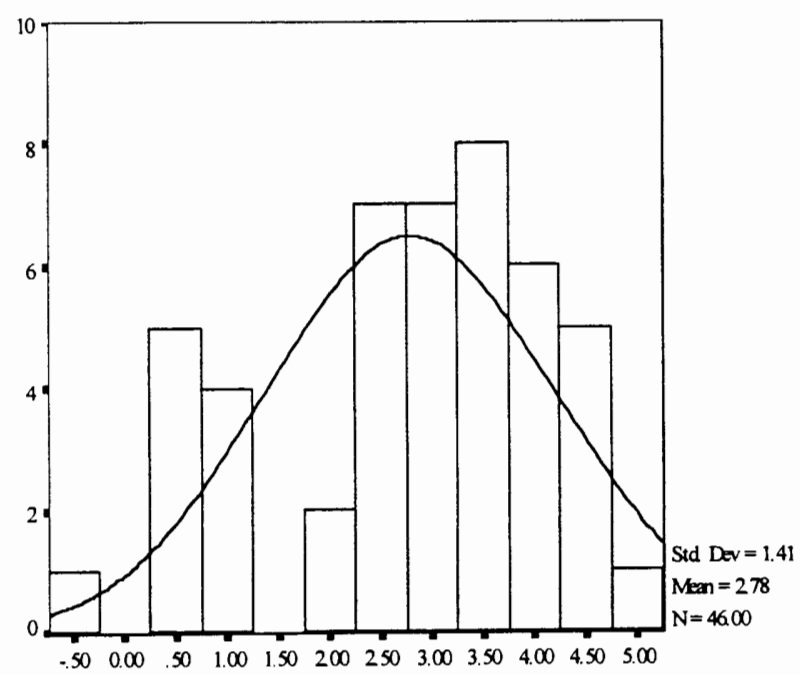

Natural log of aid measure 


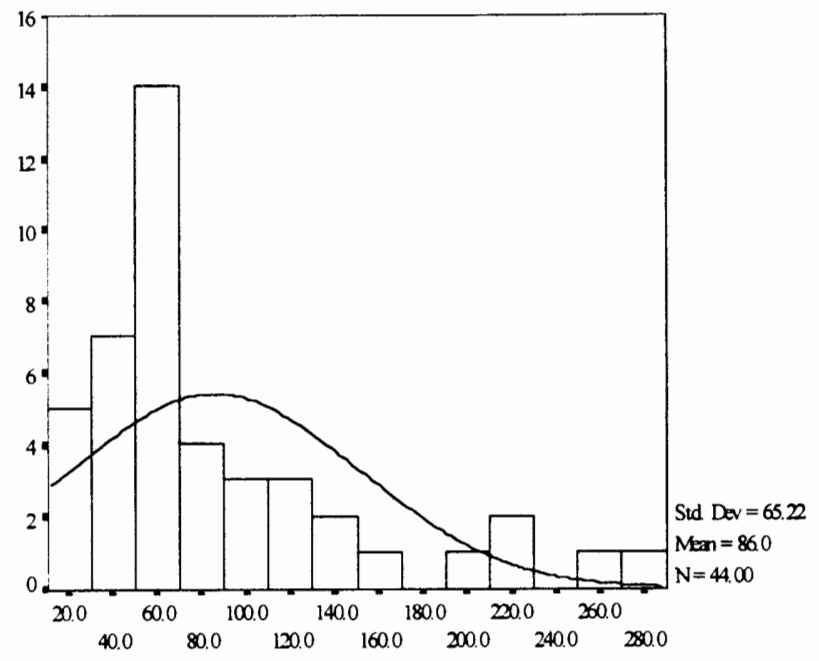

Total external debt as a \% of GNP in 1990

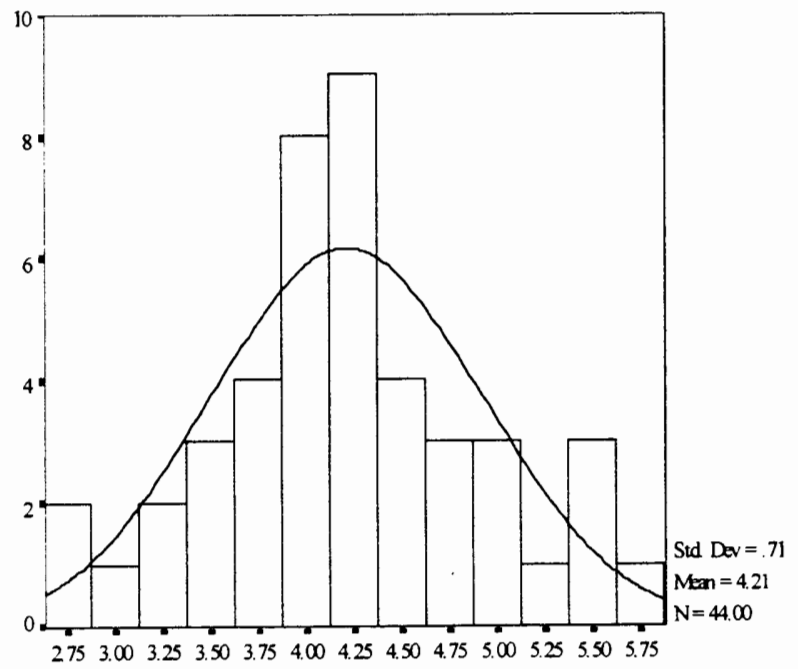

Natural log of debt measure 


\section{REFERENCES}

Ahluwalia, Montek S., 1974. "Income Inequality: Some Dimensions of the Problem." Pp. 31-42 in Development and Underdevelopment: The Political Economy of Inequality, edited by Mitchell A. Seligson and John Passé-Smith, 1993. Boulder CO: Lynne Rienner Publishers.

Anand, Sudhir and S.M.R. Kanbur, 1993. "The Kuznets Process and the InequalityDevelopment Relationship." Journal of Development Economics 40:25-52.

Bornschier, Volker and Christopher Chase-Dunn, 1985. Transnational Corporations and Underdevelopment. New York. Praeger.

Chan, Steve, 1989. "Income Inequality Among LDCs: A Comparative Analysis of Alternative Perspectives." International Studies Quarterly 33:45-65.

Crenshaw, Edward and Ansari Ameen, 1993. "Dimensions of Social Inequality in The Third World: A Cross-National Analysis of Income Inequality and Mortality Decline." Population Research and Policy Review 12:297-313.

Dixon, William J. and Terry Boswell, 1996. "Dependency, Disarticulation, and Denominator Effects: Another Look at Foreign Capital Penetration." American Journal of Sociology 102(2):543-562.

dos Santos, Theotonio, 1970. "The Structure of Dependence." Pp. 193-202 in Development and Underdevelopment: The Political Economy of Inequality, edited by Mitchell A. Seligson and John Passé-Smith, 1993. Boulder CO: Lynne Rienner Publishers.

Dunning, John and John Cantwell, 1987. IRM Directory of Statistics of International Investment and Production. New York University Press. New York.

Ehrenberg, Ronald G. and Robert S. Smith, 1994. Modern Labor Economics: Theory and Public Policy, Fifth Edition. Harper Collins College Publishers.

ILO, 1977. Labor Force Estimates and Projections: 1950-2000. International Labour Office. Geneva.

Kuznets, Simon, 1955. "Economic Growth and Income Inequality." Pp. 43-56 in Development and Underdevelopment: The Political Economy of Inequality, 
edited by Mitchell A. Seligson and John Passé-Smith, 1993. Boulder CO: Lynne Rienner Publishers.

Lecaillon, Jacques and Felix Paukert, Christian Morrison, Dimitri Germidis, 1984. Income Distribution and Economic Development. International Labour Office. Geneva.

Lipton, Michael, 1976. Why Poor People Stay Poor. Cambridge MA: Harvard University Press.

1993. "Urban Bias: Of Consequences, Classes and Causality." Journal of Development Studies. 29:229-258.

McMichael, Philip, 1996. Development and Social Change. Thousand Oaks CA: Pine Forge Press.

Nembhard, Jessica, 1993. "Foreign Aid and Dependent Development." Pp. 314-334 in Creating a New World Economy: Forces of Change and Plans for Action, edited by Gerald Epstein, Julie Graham and Jessica Nembhard, 1993. Philadelphia: Temple University Press.

Nielsen, Francois, 1994. "Income Inequality and Industrial Development: Dualism Revisited." American Sociological Review 59:654-677.

Nielsen, Francois, 1997. Personal correspondence via e-mail.

Nielsen, Francois and Arthur S. Alderson. 1995. "Income Inequality, Development, and Dualism: Results From an Unbalanced Cross-National Panel." American Sociological Review 60:674-701.

Sirowy, Larry and Alex Inkeles, 1991. "The Effects of Democracy on Economic Growth and Inequality," Pp. 389-405 in Development and Underdevelopment: The Political Economy of Inequality, edited by Mitchell A. Seligson and John Passé-Smith, 1993. Boulder CO: Lynne Rienner Publishers.

Timberlake, Michael, 1985. "The World-System Perspective and Urbanization." Pp. 3-24 in Urbanization in the World Economy, edited by Michael Timberlake. Orlando: Academic Press.

Third World Editors, 1990. Third World Guide 89/90: Facts - Figures - Opinions. Third World Editors. Montevideo. 
Tsai, Pan-Long, 1995. "Foreign Direct Investment and Income Inequality: Further Evidence." World Development 23(3):469-483.

United Nations Center on Transnational Corporations (UNCTC). 1983. Transnational Corporations in World Development: Third Survey. New York, United Nations.

Varshney, Ashutosh, 1993. "Introduction: Urban Bias in Perspective." Journal of Development Studies. 29:229-258.

World Bank, 1987. World Development Report. Oxford University Press.

World Bank, 1988. World Development Report. Oxford University Press.

World Bank, 1990. World Development Report. Oxford University Press.

World Bank, 1992. World Development Report. Oxford University Press.

World Bank, 1995. World Development Report. Oxford University Press. 


\section{ENDNOTES}

1 While not an object of empirical investigation in my paper, no discussion of inequality in LDCs would be complete without some mention of urban bias theory. In essence this perspective proposes that economic development in LDCs is biased in favor of urban areas and residents due to the political dominance of urban political elites and interest groups. Michael Lipton originated this theory and sums it up succinctly:

The most important class conflict in the poor countries of the world today is not between labor and capital. Nor is it between foreign and national interests. It is between the rural classes and the urban classes. The rural sector contains most of the poverty, and most of the low-cost sources of potential advance; but the urban sector contains most of the articulateness, organization, and power. (1976, p. 13)

This seminal work inspired an outpouring of research and policy looking at the urban bias issue in development. The urban bias perspective came to dominate more than a decade of research and policy initiatives sponsored by development agencies like the World Bank. Along the way, urban bias has been criticized for its neglect of the influence of different kinds of political systems on rural representation, ignoring other bases for identity formation (religious and ethnic) that can cut across rural-urban politics, and for skirting the issue of defining the boundary between rural and urban (Varshney, 1993).

Recently Lipton has sought to defend and clarify his hypothesis. He argues that urban bias "is defined upon outcomes, not causes or processes" (1993, p. 231). In other words, urban bias is any outcome that "persistently favors urban people vis-a-vis rural" people independent of the causal factors involved (1993, p. 231). Four dimensions of outcomes are proposed to detect the existence of urban bias: static efficiency, dynamic efficiency, income/poverty distribution, and sustainability (fiscal, administrative and environmental). Lipton argues that it is not enough to demonstrate a lack of urban bias in just one dimension (for instance commodity price indicators) in order to disprove the existence of urban bias.

In this paper I am interested in broadly conceived overall national income inequality. Urban bias posits an inter-sectoral and inter-regional income inequality that is outside the scope of this paper's goals (and incidentally virtually impossible to examine cross-nationally because of the lack of data broken down by sector). Also, urban bias as formulated by Lipton avoids specifying a causal model with specific independent variables and is thus inappropriate for the kind of cross-national inferential research I am undertaking. 
In a summary review of literature relating to the connection between democracy and inequality Larry Sirowy and Alex Inkeles (1991) found a wide variety of conflicting theories and evidence. According to Sirowy and Inkeles, Lipset (1959) argues that democratic institutions enhance equity while Beitz (1982) argues that authoritarian regimes have more potential for equity. Many Marxists on the other hand see the political system as mostly irrelevant to the issue of distributional equity.

Sirowy and Inkeles go on to review twelve research articles that examine the link between democracy and inequality. Seven studies found an inverse relationship while five others found either no link or a positive relation between inequality and democracy. Some of this variation is probably due to differences in model specification, measurement, and sample selection. The relationship between government institutions and inequality is most likely substantial. However, due to the problems associated with specification, operationalization, and data availability I will not include this as an independent variable in my analysis.

${ }^{3}$ Throughout this paper, FDI will be used to denote "investment that is made to acquire a lasting interest (usually $10 \%$ of the voting stock) in an enterprise operating in a country other than that of the investor, the investor's purpose being an effective voice in the management of the enterprise." (p. 239, World Bank, 1995) 
${ }^{4}$ Scatter plot of Kuznets' inverted U-curve:

\section{Quadratic function fitted to data}

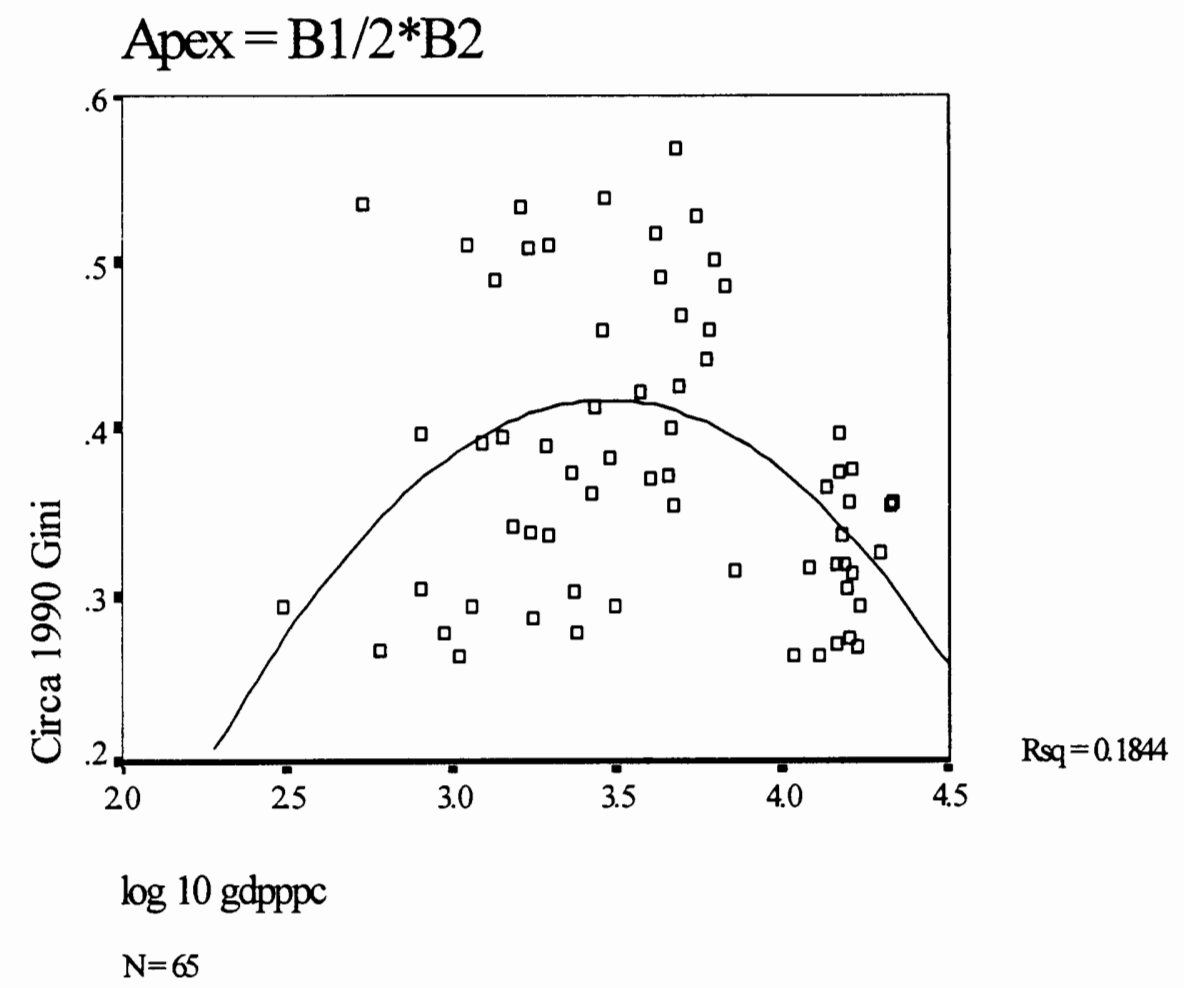

${ }^{5}$ This measure of sector dualism is derived from a special case of the Gini coefficient. See Nielsen (1994) for an extended discussion of the derivation. 